\title{
Guide to further reading
}

\section{Chapter 1}

For comparative studies of the ideological dynamics of social democratic parties see A. Przeworski, Capitalism and Social Democracy (Cambridge, 1985), T. A. Koelble, The Left Unravelled (Durham, 1991) and H. Kitschelt, The Transformation of European Social Democracy (Cambridge, 1994). R. Miliband, Parliamentary Socialism (1972), D. Coates, The Labour Party and the Struggle for Socialism (Cambridge, 1975) and L. Panitch, Social Democracy and Industrial Militancy (Cambridge, 1976) provide accounts of ideological change within the Labour Party from a Marxist perspective, while economic imperatives for ideological movement are also the focus of C. A. R. Crosland, The Future of Socialism (1963) and J. Gray, After Social Democracy: Politics, Capitalism and the Common Life (1996). R. Desai, Intellectuals and Socialism (1994) examines the role of Labour's intellectuals, while A. F. Heath, R. M. Jowell and J. K. Curtice, The Rise of New Labour (Oxford, 2001) carefully examine the electoral factors underpinning Labour's most recent ideological changes. S. Haseler, The Gaitskellites (1969) and M. Wickham-Jones, Economic Strategy and the Labour Party (1996) provide good examples of studies of the intra-party dynamics of Labour's ideological movements.

\section{Chapter 2}

Some books referred to in this chapter are now out of print, but most of the titles and all the journals are still available. Of the older works, T. Forester, The Labour Party and the Working Class (1976) and H. Drucker, Doctrine and Ethos in the Labour Party (1979) are still well worth consulting, as is, for its 'new' approach to writing political history (although about the Communist Party), R. Samuel's series in New Left Review, 154, 156, 165, published in 1985-87. J. Lawrence and M. Taylor (eds) Party, State and Society (Aldershot, 1997) provides the best guide to the 'new political history'. Studies which develop some of these themes and approaches for the Left include: S. Fielding, P. Thompson and N. Tiratsoo, England Arise! The Labour Party and Popular Politics in 1940s Britain (Manchester, 1995); L. Black, The Political Culture of the Left in Affluent Britain, 1951-64 (2003); and I. Favretto, The Long Search for a Third Way: The British Labour Party and the Italian Left Since 1945 (2002). R. McKibbin's Classes and Cultures (Oxford, 1998) and A. F. Heath, R. M. Jowell and J. K. Curtice, How Britain Votes (Oxford, 1985) are also important reading. 


\section{Chapter 3}

For the history of the New Left and an assessment of its theoretical contribution, see L. Chun, The British New Left (Edinburgh, 1993). On the early New Left, see S. Hall, 'The first New Left', in R. Archer, D. Bubeck, H. Glock, L. Jacobs, S. Moglen, A. Steinhouse and D. Weinstock (eds) Out of Apathy (1989) and M. Kenny, The First New Left (1995). Among the many works produced by New Left writers, the following relate particularly to the themes discussed here: R. Miliband, Parliamentary Socialism (1972 [1961]) and 'Moving on', The Socialist Register 1973 (1973); R. Williams, Politics and Letters (1979); R. Williams, S. Hall and E. P. Thompson (eds) The May Day Manifesto (1967); T. Nairn, The Break-Up of Britain (1977); S. Hall, The Hard Road to Renewal (1988); J. Saville, 'The ideology of Labourism', in R. Benewick, R. Berki and B. Parekh (eds) Knowledge and Belief in Politics (1975); P. Anderson, English Questions (1992); A. Barnett, This Time: Our Constitutional Revolution (1997). For criticisms of the New Left, see E. Meiskins-Wood, 'A chronology of the New Left and its successors, or: who's old-fashioned now?' The Socialist Register 1995 (1995) and R. Samuel and G. Stedman Jones, 'The Labour Party and social democracy', in R. Samuel and G. Stedman Jones (eds) Culture, Ideology and Politics (1982).

\section{Chapter 4}

The interpretation in this chapter is developed more fully in M. Newman, Ralph Miliband and the Politics of the New Left (2002) which also includes a full bibliography of Miliband's works. The Socialist Register: Why Not Capitalism? (1995), contains several articles on Miliband, including L. Panitch, 'Ralph Miliband, socialist intellectual, 1924-94' and J. Saville, 'Parliamentary Socialism revisited'. However, the best way to evaluate Miliband is to read his own work. The continuities and evolution in his analysis can be appreciated through the following: The State in Capitalist Society (1969); Parliamentary Socialism (1972); Marxism and Politics (Oxford, 1977); and Socialism for a Sceptical Age (Cambridge, 1994).

\section{Chapter 5}

For a fuller introduction to the approach discussed here, see D. Coates (ed.) Paving the Third Way: The Critique of Parliamentary Socialism: A Socialist Register Anthology (2003). On the Bennite Left and its aftermath, see L. Panitch and C. Leys, The End of Parliamentary Socialism (2001 [1997]). The second of the latter work brings the analysis through to the first term of the New Labour Government. For an important exploration of the socialist alternative and its attainment, see L. Panitch, Renewing Socialism (Boulder, CO, and Oxford, 2001); and the series of essays in L. Panitch and C. Leys (eds) The Socialist Register 2000 (2000). For an introduction to the understanding of political economy associated with the Milibandian approach, see D. Coates, Models of Capitalism (Cambridge, 2000).

\section{Chapter 6}

The original key texts by Tom Nairn and Perry Anderson are contained in the collection P. Anderson and R. Blackburn (eds) Towards Socialism (1965). Anderson's historical overview is reproduced again, along with other papers, in his 1992 collection English Questions. Overviews of the Nairn-Anderson theses are contained in L. Chun, The British New Left (Edinburgh, 1993), G. Elliot, Perry Anderson (1998) and M. Kenny, The First New Left 
(1995). For a sympathetic, if polemical, application to Labour history, see G. Elliott, Labourism and the English Genius (1993).

\section{Chapter 7}

There is an interesting video of Henry Pelling interviewed by Ross McKibbin, made in 1988 and available from the Institute of Historical Research. Clearly, the central work to consider is H. Pelling, The Origins of the Labour Party, 1880-1900 (Oxford, 1954), which was so thoroughly researched and clearly presented that it remains a classic reference point. Pelling's further pursuit of the issues of the regional and ideological fragmentation of the working classes was published in Social Geography of British Elections, 1885-1910 (1967) and Popular Politics and Society in Late Victorian Britain (1968). His approach has been influential on more recent work such as D. Tanner, Political Change and the Labour Party, 1900-1918 (Cambridge, 1990), and many of the essays in E. F. Biagini and A. J. Reid (eds) Currents of Radicalism. Popular Radicalism, Organised Labour and Party Politics in Britain, 1850-1914 (Cambridge, 1991).

\section{Chapter 8}

The interested reader should start with McKibbin's own books - The Evolution of the Labour Party (Oxford, 1974); The Ideologies of Class (Oxford, 1990); and Classes and Cultures (Oxford, 1998). McKibbin's treatment of the 'exceptional' development of working-class politics in Britain might be compared with Tom Nairn's earlier expositions of this argument in 'The English working class', New Left Review, 24 (1964) and 'The fateful meridian', New Left Review, 60 (1970). The argument is systematically questioned in Stefan Berger, The British Labour Party and the German Social Democrats (Oxford, 1994). McKibbin's treatment of the relationship between working-class culture and working-class politics is usefully compared with Gareth Stedman Jones's 'Working class culture and working class politics in London, 1870-1900', Journal of Social History, 7:4 (1974) and the same author's Languages of Class (Cambridge, 1982). Finally, those interested in the documentary sources for generalisations about working-class cultures should read Jonathan Rose's The Intellectual Life of the British Working Classes (2001).

\section{Chapter 9}

In terms of the historical debate, P. Clarke, Lancashire and the New Liberalism (Cambridge, 1971) makes the most convincing case for the existence of a viable 'progressive alliance', though this has been most recently challenged by D. McHugh, 'Labour, the Liberals and the progressive alliance in Manchester, 1900-14', Northern History, 39:1 (2002). R. Desai's Intellectuals and Socialism (1994) is a good place to start to acquire an overview of the place held by social democratic intellectuals within the Labour Party. P. Clarke's 'The social democratic theory of the class struggle', in J. Winter (ed.) The Working Class in Modern British History (Cambridge, 1983) provides a concise summation of their developing perspective until the formation of the SDP, while the essays contained in D. Marquand, The Progressive Dilemma (1999), are important to an understanding of the perspective from the later 1980s up to the formation of 'New' Labour. P. Gould, The Unfinished Revolution (1998), sketches out how 'New' Labour has appropriated the debate. 


\section{Chapter 10}

Of the monographs on the unions-party link, Lewis Minkin's The Contentious Alliance (Edinburgh, 1992) is by far the most extensive and detailed, and focuses on the dynamics of the intra-party relationship. Pluralist perspectives on the link across much of the postwar period, and focused on unions-government relations, can be traced in Robert Taylor's The Trade Union Question in British Politics (Oxford, 1993), and, for a shorter but crucial period, in Gerald Dorfman's Government versus Trade Unionism in British Politics Since 1968 (1979). Marxist analyses, again mainly of the unions-government relationship, are to be found in Leo Panitch's Social Democracy and Industrial Militancy (Cambridge, 1976), and in David Coates's The Crisis of Labour (Oxford, 1989). The best book-length treatment of the link during the key period on which the chapter focuses remains Andrew J. Taylor's The Trade Unions and the Labour Party (1987).

\section{Chapter 11}

Top of the list are Minkin's two magisterial studies The Labour Party Conference (1978) and The Contentious Alliance (Edinburgh, 1991. These are towering works which no serious student of the Labour Party can afford to ignore. Minkin's earlier treatments of the party-unions connection can be found in: 'The British Labour Party and the trade unions: crisis and compact', Industrial Labour Relations Review, October (1974); 'The party connection: divergence and convergence in the British labour movement', Government and Opposition, 13:4 (1978); and 'Leftwing trade unionism and tensions of British Labour politics', in B. E. Brown (ed.) Eurocommunism and Eurosocialism: The Left Confronts Modernity (New York, 1978). There are also some fascinating insights on Minkin's method and research techniques in his Exists and Entrances (Sheffield, 1997).

Elements of Minkin's interpretive framework have been applied to developments in the party-unions relationship over the last decade by Steve Ludlam. See 'New Labour and the unions: the end of the contentious alliance?' in S. Ludlam and M. J. Smith (eds) New Labour in Government (2001) and S. Ludlam, M. Bodah and D. Coates, 'Trajectories of solidarity: changing union-party linkages in the UK and the USA', British Journal of Politics \& International Relations, 4:2 (2002). The topic of party-unions relations has also been treated in the following studies by John Mcllroy: 'The enduring alliance? Trade unions and the making of New Labour, 1994-97', British Journal of Industrial Relations (1998), 36:4; 'New Labour, new unions, new Left', Capital and Class, 71 (2000); and 'The new politics of pressure - the Trades Union Congress and New Labour in government', Industrial Relations Journal, $31: 2$ (2000). The subject is discussed also in C. Howell, 'From New Labour to no Labour? The industrial relations project of the Blair Government', New Political Science, $22: 2(2000)$.

\section{Chapter 12}

The literature on the analytical techniques appropriate to labour studies is very limited indeed. There is, however, a broader political science literature on which labour studies might draw. That literature is introduced and reviewed in C. Hay, Political Analysis (2002), and D. Marsh and G. Stoker (eds) Theory and Methods in Political Science (2002). For an attempt to draw out the implications of this literature for postwar British politics, see D. Marsh et al., Postwar British Politics in Perspective (Cambridge, 1999). For debates within labour studies which draw attention to these issues, see especially, D. Coates, 'Capitalist 
models and social democracy: the case of New Labour', British Journal of Politics \& International Studies, 3:3 (2001), as well as C. Hay, The Political Economy of New Labour (Manchester, 1999) and 'Globalisation, EU-isation and the space for social democratic alternatives: pessimism of the intellect . . ., British Journal of Politics \& International Relations, 4:3 (2002). 
John Callaghan, Steven Fielding, and Steve Ludlam - 9781526137456 Downloaded from manchesterhive.com at 04/26/2023 10:12:59AM via free access 